\title{
$\mathrm{CR}$ システムのパノラマ X 線撮影法への応用
}

\author{
新田昭洋・牧＼cjkstart正啓・宇治保義 \\ 桑田清美・加藤理恵・野田信夫 \\ 後藤千恵・愛甲＼cjkstart徹・田縁＼cjkstart昭
}

\section{Application of CR system to Panoramic roentgenography}

\author{
Akihiro NitTA - Masahiro MAKI - Yasuyoshi UJI \\ Kiyomi Kuwata - Rie Kato - Nobuo Noda \\ Chie Goto • Toru Arko • Akira TaEN
}

\begin{abstract}
The CR system has been applied to almost all types of roentgenography. In oral surgery, it has been used for special techniques such as panoramic roentgenography, conventional radiography of the head, and tomography of the jaw joint as well as for extraoral techniques including the frontal radiography of the head with favorable results.

In this study, we employed this CR system in panoramic roentgenography, which is performed frequently in oral surgery, to evaluate its abilities to delineate (1) anatomical structures and (2) lesions.

(1) Ability to delineate anatomical structures.

The bone structures, borders of the cortical bone, and the relationship between the root of the tooth and the jaw bone were more clearly represented, and the blur in the anterior teeth region characteristic of tomography was slightly reduced.

(2) Ability to delineate lesions.

The course of fracture lines, margins of cysts and tumors, relationship between the implanted tooth and the jaw bone, and anatomical structures around the lesions of siagonantritis were more readily evaluated, suggesting improved imaging ability of the CR technique.
\end{abstract}

Key words: computed radiography, panoramic roentgenography

緒

\section{言}

近年，放射線診断の分野に扣ける新しい技術と装置の 開発には目ざましいものがある。口腔外科領域において も, CT, MRI, digital radiography など，従来の撮影 法と比較してょり多くの情報を得られる方法が用いられ つつある。

Computed radiography（以下 CR と略す）はわが 国で独自に開発されたデジタルX線画像診断システムで

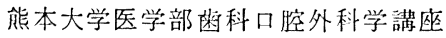

（主任：田縁 昭教授）

Department of Dentistry and Oral Surgery, Kumamoto University Medical School (Chief: Prot. Akira Taen)

受付日：昭和 63 年 4 月 28 日
ある.この方式は従来のX線装置を用いて，X線吸収值 の変化を輝尽性螢光体である imaging plate（以下 IP と略す）に記録した後，デジタル信号に変換，さらにコ ンピューター処理を行って, 専用のフィルム上に画像と して再現するものである. 本システムは医学領域の分野 に执いてその診断学的価值が認められ多くの報告がなさ れている1,2).

昭和60年10月，本院中央放射線部にこの CR システ ムが導入され, 当教室に执いても各種口腔外科疾患領域 の診断に利用している.

今回，われわれはこの方式を口腔外科領域で特に使用 頻度の高いパノラマX線撮影への応用を試み，診断上の 画質の向上性と情報量について，通常法と比較検討した ので報告する。 


\section{対 象 症 例}

症例は昭和 61 年 12 月から 62 年 11 月までの 1 年間に当科 を受診した患者で，通常法と CR 法でパノラマX線撮 影を行った症例中，䋶骨骨折13例，䫇骨霆胞13例，顎骨 腫瘍 15 例, 埋伏歯16例, 上顎洞炎 10 例, 計 67 例を対象と した。

\section{装置および方法}

\section{1. $\mathbf{C R}$ システム}

撮影装置は従来のX線発生装置を用い，X線センサー として，高分子支持体上にハロゲン化合物の結晶を充填 染布した厚さ $1 \mathrm{~mm}$ 弱の IP を用いる。 X 線撮影後, IP に記録されたX線情報をレーザービームにて走查す る。得られた信号は A/D 变换し, 診断目的に応じて, 任意のプログラミングにもとづき演算処理が行われる。 このよらにして処理されたデジタル情報を再びレーザー 光を使って, 専用のフィルムに記録し現像処理すること でX線像を作り出す（図1）。

\section{2. 撮影法}

X線装置はオルソパントモグラフィー100２00（朝日

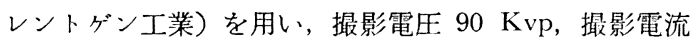

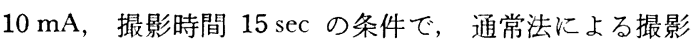
と CR 法による撮影を可能な限り同じ条件で行った。

\section{3. 画像処理}

使用した装固は CR 201型（富士メディカル社）で， 階調処理, 空間周波数処理の二つの画像処理を主体とし て多様な画像を得ることが可能である。

階調処理とは, 露光量とフィルム上の峘度との関係を 決定寸る特性曲線を演算処理で任意に選択する方法であ る。この処理により寞容度の広い画像, つまり低漕度部 分もよく拾う画像からコントラストの強い画像まで再構 成することができる，また空間周波数処理は，ある特定 の空間周波数領域を強調させ鮮鋭度を調節する方法で,

この処理によりェッジ効果の高い画像を得ることが可能 である。

今回は，症例によって個別化した処理を行わず，当科 によってあらかじめ最適と定めた条件で画像処理を行っ た。 な打空間分解能は $0.71 \mathrm{c} / \mathrm{mm}$ とし，この周波数近 傍の辺縁を強調した。

\section{4. 比較検討方法}

パノラマX線撮影において，通常法による振影像と $\mathrm{CR}$ 法による画像について, (1)解剖構造の描出能, (2)病 変の描出能に分けて比較検討した。

1）解剖構造の描出能としては，67症例中，25症例を 選択し，それぞれ通常観察される㭢造として骨稜，境 界, 部位別として前棶部, 㴿関節部, 上顎洞部の 5 項目

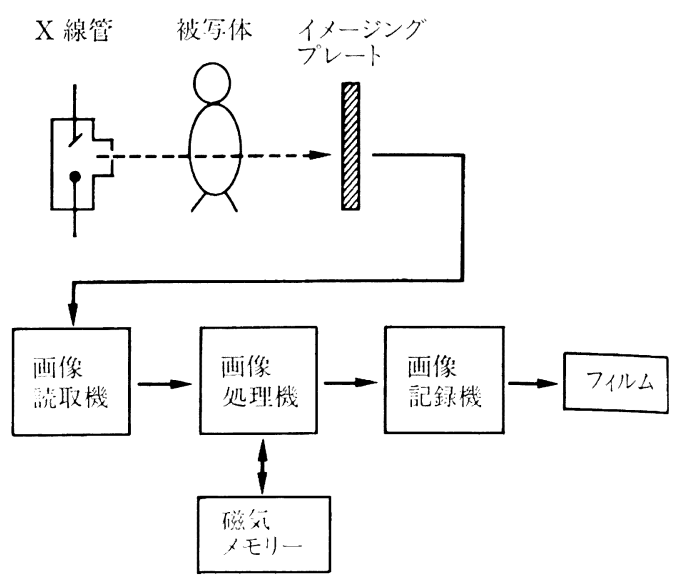

図 $1 \mathrm{CR}$ システム

表 1 描出能の評価基淮

\begin{tabular}{c|c}
\hline 評 価 & \multicolumn{1}{|c}{ 判 定 基 準 } \\
\hline-2 & CR の描出能が非常に劣る \\
-1 & CR の描出能がやや劣る \\
0 & とちらともいえない \\
1 & CR の描出能がやや優れている \\
2 & CR の描出能が非常に優れている \\
\hline
\end{tabular}

に分類し比較検討した。

2 ) 病変の描出能としては，67症例を臨床上骨折，賴 胞, 腫瘍, 埋伏州, 上顎洞炎の 5 項目に分類し比較検討 した.

評価基準は, 画像の描出能について両者同等を 0 と し，各優劣によって -2 から 2 までの 5 段階とした（表 1). 画像評価は歯科医師 4 名で判定し, 各評価值の症 例数とその割合 (百分率), また $\mathrm{CR}$ 画像の描出能の向 上程度（評侕 1 または評価 2 ）を求めた。

\section{結果}

\section{1. 解剖構造の描出能}

CR 画像が通常法による撮影像より劣る評価は 1 例も なく, CR 画像の描出能の向上性が認められた。

骨稜構造の表現，骨皮質の辺縁境界，崡根と買骨との 関係など描出能の向上性が認められ，特に前齿部に执い ては，断層撮影特有のボケ像が若干改善される傾向がう かがわれた（表 2).

\section{2. 病変の描出能}

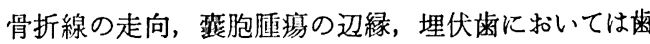
牙と䫇骨との関係，上顎洞炎に扣いても，病巣周团の解 剖学的蹅造が読影しやすく, CR 画像の描出能の向上が 
表 2 解剖構造の描出能（検者 4 人の合計）

\begin{tabular}{|c|c|c|c|c|c|c|c|c|c|c|}
\hline \multirow{2}{*}{ 評価 } & \multicolumn{2}{|c|}{ 骨稜 } & \multicolumn{2}{|l|}{ 境 } & \multicolumn{2}{|c|}{ 前 柴 部 } & \multicolumn{2}{|c|}{ 顥関節 部 } & \multicolumn{2}{|c|}{ 上顎洞部 } \\
\hline & 症例数 & $\%$ & 症例数 & $\%$ & 症例数 & $\%$ & 症例数 & $\%$ & 症例数 & $\%$ \\
\hline-2 & 0 & 0 & 0 & 0 & 0 & 0 & 0 & 0 & 0 & 0 \\
\hline-1 & 0 & 0 & 0 & 0 & 0 & 0 & 0 & 0 & 0 & 0 \\
\hline 0 & 2 & 2 & 8 & 8 & 27 & 27 & 62 & 62 & 21 & 21 \\
\hline 1 & 43 & 43 & 53 & 53 & 42 & 42 & 33 & 33 & 59 & 59 \\
\hline 2 & 55 & 55 & 39 & 39 & 31 & 31 & 5 & 5 & 20 & 20 \\
\hline $1+2$ & 98 & 98 & 92 & 92 & 73 & 73 & 38 & 38 & 79 & 79 \\
\hline
\end{tabular}

表 3 病変の描出能（检者 4 人の合計）

\begin{tabular}{|c|c|c|c|c|c|c|c|c|c|c|}
\hline \multirow{2}{*}{ 評価 } & \multicolumn{2}{|r|}{ 折 } & \multicolumn{2}{|l|}{ 榇 } & \multicolumn{2}{|c|}{ 腫瘍 } & \multicolumn{2}{|c|}{ 埋伏歯 } & \multicolumn{2}{|c|}{ 上顎洞炎 } \\
\hline & 症例数 & $\%$ & 症例数 & $\%$ & 症例数 & $\%$ & 症例数 & $\%$ & 症例数 & $\%$ \\
\hline-2 & 0 & 0 & 0 & 0 & 0 & 0 & 0 & 0 & 0 & 0 \\
\hline-1 & 0 & 0 & 0 & 0 & 0 & 0 & 0 & 0 & 1 & 2.5 \\
\hline 0 & 15 & 28.8 & 5 & 9.6 & 26 & 43.3 & 18 & 28.1 & 15 & 37.5 \\
\hline 1 & 24 & 46.2 & 29 & 55.8 & 22 & 36.7 & 37 & 57.8 & 19 & 47.5 \\
\hline 2 & 13 & 25.0 & 18 & 34.6 & 21 & 20.0 & 9 & 14.1 & 5 & 12.5 \\
\hline $1+2$ & 37 & 71.2 & 47 & 90.4 & 34 & 56.7 & 46 & 71.9 & 24 & 60.0 \\
\hline
\end{tabular}

認められる傾向がらかがわれた（表了）.

今回比較検討した症例の中より，CR 法と通常法に拉 けるオルソパントモ撮影像の 2 例を供覧する。

症例

\section{症例 1}

患 者: 28 歳 男性.

診断名：下顎正中部，右側下顎枝糈骨折.

1) 解剖構造の描出能

CR 画像は通常法の撮影像と比較して，ほとんどすべ

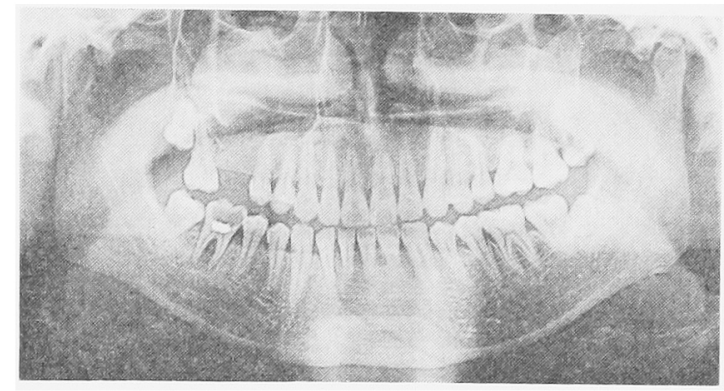

写真 1 CR 法K上る撮影像（症例 1）

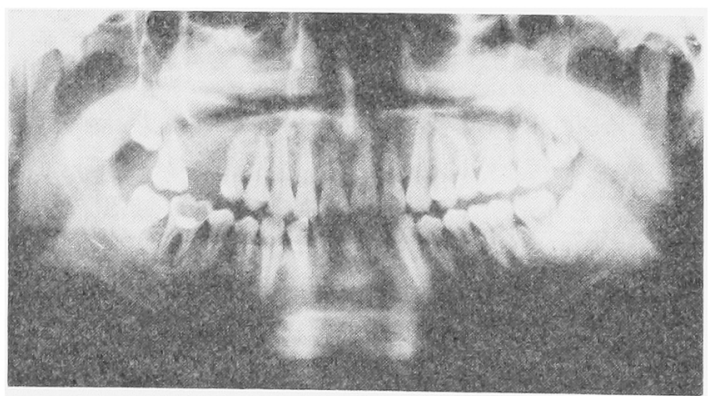

写真 2 通常法に上る撮影像（症例 1) 


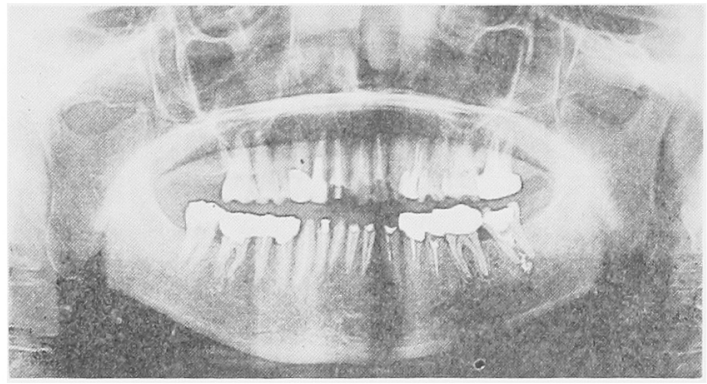

写真 $3 \mathrm{CR}$ 法に上る撮影像（症例 2）

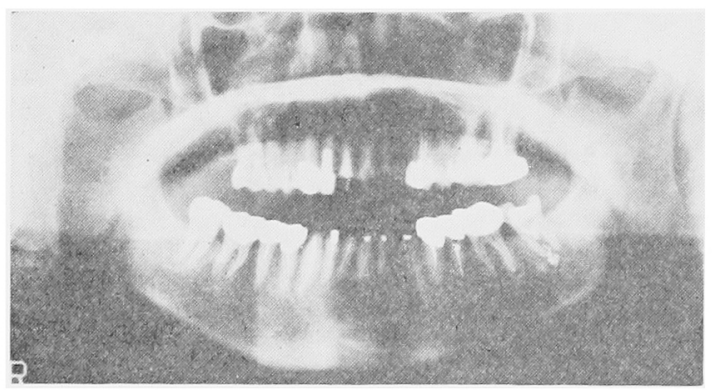

写真 4 通常法化上る撮影像（症例 2)

\section{症例 2}

患 者: 42 歳 女性.

診断名: $\overline{1 \mid 123}$ 部崡根嫼胞.

1) 解剖粠造の描出能

CR 画像は通常法の撮影像と比較して，ほとんどすべ ての部位に抋いて骨稜構造, 歯根, 歯䯣腔の形態がより 鮮明でまた前崡部に扎いてボケ像がわずか改善され る傾向がらかがわれた。

2) 病变の描出能

CR 画像舮常法の撮影像と比較して, 亦胞の境界が 鮮明で，襄胞底部の一層の骨硬化栏不透過像，さらに $\overline{1 \mid 123}$ の根尖が栾胞に包含されている様相がより明膫 にみとめられた（写真 3，4）。

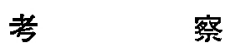

CR システムは，ほとんどすべてのX線撮影の対象に なり，口腔外科領域に扣いても頭部X線単純撮影法をは じか, ペノラマX線熶影法, 頭部X線規格撮影法, 枵関節 断層撮影法などの特殊撮影法にも応用が進められ，その 有用性についての報告る散見されているよらである ${ }^{3 \sim 6)}$.

今回，われわれはこの CR システムを，口腔外科領 域で特に使用頻度の高いパノラマX線撮影飞応用し, (1) 解剖構造の描出能, (2)病変の描出能に分けて CR 画像 の描出能を検討した。

解剖棈造の描出能に执いて, CR 画像は階調処理, 空
間周波数処理を行らことにより宽容度を広くし、ェッジ 効果を発揮させ，骨稜などの微細な構造，骨皮質などの 解剖学的境界が鮮鋭となるよらであった. これらのこと から齿牙と顎骨，上䫑洞との解剖学的関係，下畨槽管の 走向, 雪牙や齿槽頂縁の解剖学的形態が解読しやすく描

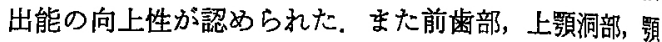
関節部の各部位ごとに比較しても，解剖学構造が比較的 容易に把握することができ，特に前齿部に批いては，断 風撮影特有のボケ像が若干改善される傾向がらかがわれ た。

病変の描出能での骨折症例に括いて, 従来バノラマX 線撮影像では, 莗裂骨折, 不完全骨折の場合, 骨折線の 読影がしばしば困難である。 それと比較して，CR 画像 に和いては，寛容度が広くなり、エッシ效果が発揮され ることにより，コントラスト不足が改善され，微細な浱 淡差を描出することが可能である。このため骨折線の走 向が容易に把握できるようであった，他の疾患において む同様に，解剖構造の描出能の向上を反映し，震胸，瘇 湯の辺縁や境界，埋伏齿，括上びその周囲組織，上影洞 资の病巣の存在が把握しやすくなり，歯牙などの解剖学 的関連も含めその有用性が認められた。

この CR システムの臨床応用に括いてや中不满を覚 えることは，フィルム上の画像が従来のるのより $2 / 3$ K 縮小されることであった。 しかし，画像処理を行らこと によって解鋭な画像が得られ，また多少不適切なX線露 光が行われてる自動感度調節機構も備克て特り均一て安 定した画像が得られる点も有用であった，さらに1回の 撮影註， CR フィルム1枚上に異なった処理下の 2 種類の画像が得られ，同時に観察することができる。こ れらのことから通常法と比べて, 診断がより確実なむの となり治療に貢献するものと考えられた。また，CR シ ステムは低線量撮影す可能であることから 害の危険性も減少することが考えられる。ささらに将来す でにデシタルメモリー化されている CT ,RI, MRI な どを含めて, 画像の効率的な保管, 検索, 伝送のための 総合的なシステム (PACS: picture archiving and communication system) に取り入れることができ，今後口 腔外科の䛦療体系の中で，重要な役割を担いうる可能性 があることが推察された。

結

語

今回，われわれは $\mathrm{CR}$ システムを，口腔外科領域で 特に使用頻度の高いハンラマX線撮影飞応用し，(1)解剖 構造の描出能，(2)病変の描出能に分けて CR 画像の描 出能を検討し，その有用性を認めたので報告した。

稍を終えるにあたり，こ烈篤なるこ指尊，こ数示を晹 った熊本大学医学部放射線科教室高㙫陸正教授, 吉岡仙 
珎助手ならびに中央故射線部の各位に対し，心から感䛄 の意を表します。

本諭文の要旨は，第50回日本口腔外科学会九州地方部 会（昭和62年 2 月 21 日，長崎）において発表した。

\section{引用文 献}

1) 蜂屋順一, 是永建雄, 他: Digital angiography の新しい試み。臨放 27：705-710 1982.

2) Sonoda, M., Takano, M., et al.: Computed radiography utilizing scanning laser stimulated luminescence. Radiology 148: 833-838 1983.

3) 中村哲, 塩田覚, 他：パノラマ $\mathrm{X}$ 線撮影に
よる Fuji Computed Radiograhy の检討. 口 科誌 32：1465-1471 1986.

4）堂原義美, 末永重明, 他: Fuji Computed Radiography の顎・顔面領域への応用について。菻 放 25: 96-101 1985.

5) Kashima, I., Kanno, M., et al.: Computed panoramic tomography with scanning laserstimulated luminescence. Oral Surg 60: 4484531985.

6) 鹿島勇一, 閑野政則, 他: 最近の ME 機器の 進歩一Laser sacn system によるパノラマ撮影 法. 歯界展望 64：635-643 1984.

7) 飛田 明, 香坂誠, 他: 医用画像データ一管 理の合理化の検討. 映像情報 18：77-84 1986. 